\title{
PENGUATAN USAHA PRODUKTIF MASYARAKAT MELALUI PENDAMPINGAN UKM DI DESA SUMBERAGUNG KECAMATAN NGANTANG KABUPATEN MALANG
}

\author{
Trisetia Wijijayanti' ${ }^{1)}$; Agung Winarno ${ }^{2)}$; Yuli Agustina $^{3)}$; Andi Basuki ${ }^{4)}$ \\ Universitas Negeri Malang ${ }^{1,2,3,4)}$
}

\begin{abstract}
ABSTRAK
Tujuan kegiatan pendampingan UKM di Desa Sumberagung Kecamatan Ngantang Kabupaten Malang bekerjasama dengan mitra Kelompok PKK Desa Sumberagung adalah untuk meningkatkan pendapatan mitra dengan cara memproduksi dan memasarkan produk olahan susu sapi. Permasalahan yang dihadapi mitra adalah kurangnya pengetahuan dalam hal pengelolahan hasil susu sapi yang selama ini hanya sebatas disalurkan kepada KUD setempat dan pabrik pengepul susu murni, tidak mengetahui cara pemasaran produk olahan susu sapi. Berangkat dari permasalahan tersebut, perlu diadakan pendampingan UKM kelompok PKK Desa Sumberagung melalui pelatihan pengolahan susu sapi menjadi produk unggulan desa dan dapat dijadikan sebagai produk khas Desa Sumberagung. Oleh karena itu, metode pelaksanaan yang dilakukan dalam kegiatan ini dengan memberikan informasi tentang gambaran variasi produk olahan susu sapi yang dapat membantu meningkatkan pendapatan kelompok PKK, pelatihan dan pendampingan pengelolahan susu sapi menjadi produk bernilai jual, pelatihan dan pendampingan soft skill motivasi kerja dan creative thinking, serta pelatihan pendampingan pemasaran. Hasil dari kegiatan ini adalah meningkatnya pengetahuan dan ketrampilan mitra, terciptanya produk olahan susu sapi yang bernilai jual serta mampu mendukung program Desa Sumberagung sebagai salah satu desa wisata di Lingkar Selorejo, publikasi pada media massa, serta adanya media sosial yang dapat mendukung dalam memasarkan potensi desa secara luas.
\end{abstract}

Kata kunci: pendampingan UKM, usaha produktif, kabupaten malang

\begin{abstract}
The purpose of SME assistance activities in Sumberagung Village, Ngantang District, Malang Regency in collaboration with Sumberagung Village PKK Group partners is to increase partner income by producing and marketing cow dairy products. The problem faced by partners is the lack of knowledge in the management of cow's milk products which so far have only been channeled to the Koperasi Unit Desa (KUD) and cow milk collectors, not knowing how to market cow dairy products. Departing from these problems, it is necessary to provide assistance to UKM of Sumberagung Village PKK group through training in processing cow's milk into the village's superior products and can be used as a typical product of Sumberagung Village. Therefore, the method of implementation carried out in this activity by providing information about a variety of cow dairy products that can help increase the income of the PKK group, training and mentoring the management of cow's milk into value-selling products, training and mentoring soft skills work motivation and creative thinking and marketing assistance training. The results of this activity are increased partner knowledge and skills, the creation of cow dairy products that are worth selling and able to support the Sumberagung Village program as one of the tourist villages in Lingkar Selorejo, publications in the mass media, and the existence of social media that can support the potential of the village extensively.
\end{abstract}

Keywords: SME assistance, productive business, Malang district

\section{PENDAHULUAN}

Desa Sumberagung termasuk ke dalam wilayah kecamatan Ngantang Kabupaten Malang yang memiliki 6 dusun yang tersebar di wilayahnya yaitu dukuh Sumbermulyo, Dermosari, Sumbergadung, Rejosari,
Kebonsari, dan Bendorejo. Adapun Luas Wilayah Desa Sumberagung mencapai 756.688, Ha dengan kepadatan penduduk 5.568 Jiwa. Masyarakat Desa Sumberagung didominasi oleh kelompok usia produktif sebesar $77,35 \%$ atau 
sebanyak 4.307 Jiwa dari total penduduk sebesar 5.568 Jiwa. Komposisi mata pencaharian penduduk Desa Sumberagung mayoritas bekerja di sektor pertanian, peternakan, dan perdagangan. Mayoritas lahan Desa Sumberagung merupakan Hutan dengan luas mencapai $291.300 \mathrm{Ha}$, dan penggunaan lahan lainnya berupa persawahan, pemukiman, tegalan, dan lain sebagainya. Hasil pertanian dan perkebunan cukup banyak dihasilkan di wilayah ini seperti Kopi, Padi, dan Duren. Di Wilayah Hutan desa Sumberagung banyak juga terdapat tanaman bambu, yang sering dimanfaatkan hasilnya oleh masyarakat untuk membuat tusuk sate.

Selain hasil pertanian dan perkebunannya, Desa Sumberagung juga memiliki potensi peternakan sapi perah yang menjadi mata pencaharian $70 \%$ warganya, berikut keindahan alam yang cukup menjanjikan, di Dukuh Bendorejo terdapat dataran tinggi yang menawarkan keindahan alam berupa danau, bukit, dan panorama terbenamnya matahari dengan jelas. Desa Sumberagung terdapat berbagai usaha yang dikembangkan oleh masyarakat sekitar mulai dari perdagangan, peternakan, pertanian, perkebunan. Adanya Organisasi pemerintahan/Swadaya masyarakat seperti KUD, Koperasi Wanita, dan BUMDES di Wilayah Desa Sumberagung menjadi salah satu faktor penunjang perekonomian di desa tersebut. Masyarakat Desa Sumberagung memiliki antusiasme yang tinggi untuk turut serta dalam mensukseskan pengembangan potensi ekonomi produktifnya. Antusiasme dan partisipasi masyarakat merupakan salah satu kunci kesuksesan pengembangan desa ini, khususnya dari kelompok PKK desa sumberagung. Riset yang dilakukan oleh Rahayu (2009) menyebutkan bahwa akses dan kontrol perempuan pelaku usaha mikro terhadap modal dan teknologi masih sangat terbatas, demikian juga terhadap sumber daya produktif yang bersifat non fisik/sosial seperti program pelatihan dan pendidikan.

\section{MASALAH}

Permasalahan utama yang dihadapi oleh pemilik UKM Desa sumberagung yaitu terkait keterbatasan pengetahuan yang dimiliki dalam manajerial usaha. Hal ini mengakibatkan usaha produktif sulit untuk berkembang dengan baik. Permasalahan kedua yakni terkait inovasi produk. Meskipun terdapat potensi sumberdaya yang besar di sekitar desa, namun jika masyarakat desa tidak memanfaatkannya dengan baik hal itu akan sia-sia. Seringkali masyarakat desa hanya menjual produk-produknya secara instan tanpa ada "value added" yang diberikan pada produk yang dihasilkan, padahal jika masyarakat mampu melakukan inovasi produk dan menciptakan "value added" yang optimal akan dapat meningkatkan kesejahteraan masyarakat lebih baik. Permasalahan ketiga yang dihadapi yakni produktivitas usaha yang masih tergolong rendah. Permasalahan terakhir yang dihadapi yakni terkait penyerapan tenaga kerja baru di wilayah desa Sumberagung masih terbatas. Oleh sebab itu, diperlukan adanya upaya dalam pengembangan usaha produktif, serta pendidikan Sumber daya manusia yang tepat bagi masyarakat desa sehingga akhirnya mampu menjadi motor penggerak perekonomian desa. Pelatihan dan 
pendampingan yang telah dilakukan menghasilkan dampak yang baik dilihat dari antusiasme keikutsertaan masyarakat desa dan keinginan untuk mendapatkan kegiatan sejenis yang dapat meningkatkan perekonomian desa menjadi lebih baik. Indikator yang digunakan untuk mengukur keberhasilan kegiatan pendampingan UKM pada Kelompok PKK Desa Sumberagung seperti pada tabel 1 .

Tabel 1 Target Luaran Program Kegiatan Pendampingan

\begin{tabular}{|c|c|}
\hline Aspek & Target Luaran Program IbM \\
\hline Produk & $\begin{array}{l}\text { - Mitra mampu menghasilkan varian produk olahan susu sapi berupa } \\
\text { kerupuk susu, stik susu, yogurt, keju dan sabun susu yang berkualitas } \\
\text { dan memenuhi selera pasar. } \\
\text { - Jumlah dan kualitas produksi meningkat. }\end{array}$ \\
\hline $\begin{array}{c}\text { Manajemen } \\
\text { usaha }\end{array}$ & $\begin{array}{l}\text { - Mitra mampu melakukan pemasaran menggunakan jejaring sosial } \\
\text { untuk meningkatkan pangsa pasar } \\
\text { - } \quad \text { Mitra mampu membuat laporan keuangan secara sederhana } \\
\text { - } \quad \text { Keahlian dan ketrampilan Sumber Daya Manusia dalam proses } \\
\text { produksi meningkat. } \\
\text { - } \quad \text { Motivasi dan jiwa kewirausahaan mitra meningkat } \\
\text { - Kepercayaan diri sebagai pengusaha UKM meningkat dengan adanya } \\
\text { tambahan ketrampilan yang telah didapat }\end{array}$ \\
\hline $\begin{array}{c}\text { Paten (Ijin } \\
\text { Usaha) }\end{array}$ & a pada produk yang dihasilkan. \\
\hline
\end{tabular}

Partisipasi kelompok PKK Desa Sumbergaung menjadi kunci keberhasilan dalam seluruh kegiatan di atas. Sehingga diperlukan optimalisasi partisipasi dari Mitra berupa:

a. Keikutsertaan dalam kegiatan pelatihan.

b. Partisipasi dalam menyediakan dukungan tidak langsung terhadap pelaksanaan kegiatan, seperti tempat, perlengkapan, dan konsumsi.

c. Partisipasi pembiayaan untuk keberlanjutan program kegiatan ini.

\section{METODE}

Metode Pelaksanaan pendampinga UKM di Desa Sumberagung Kecamatan Ngantang Kabupaten
Malang ini dengan memberikan informasi, pelatihan dan pendampingan.

Tahapan pelaksanaannya melalui Pendekatan dengan perangkat desa setempat dan kelompok PKK desa untuk mengetahui usaha produktif yang perlu dikembangakan dengan pemanfaatan potensi desa yang salah satunya dari hasil susu sapi, Mendata macam-macam kebutuhan kelompok PKK untuk mengembangkan UKM Desa, Pelatihan dan pendampingan pengelolahan susu sapi menjadi produk bernilai jual, pelatihan dan pendampingan softskill motivasi kerja dan creative thinking, serta pelatihan pendampingan pemasaran. 


\section{PEMBAHASAN}

Kegiatan Penguatan Usaha Produktif Masyarakat Melalui Pendampingan UKM Di Desa Sumberagung Kecamatan Ngantang Kabupaten Malang dimulai dengan kegiatan Observasi dan FGD di Desa Sumberagung bersama perangkat desa setempat, ketua PKK dan seluruh UKM yang ada. Saat ini perkembanagn potensi desa untuk menjadi desa wisata sangat besar, hal ini dapat dilihat dari banyakanya desa-desa yang mendeklarasikan diri sebagai desa wisata dengan berbagai potensi yang dimiliki. Kesiapan sebuah desa untuk menjadi desa wisata perlu adanya dukungan baik potensi yang dimiliki desa serta SDM yang mendukung dalam perwujudan tersebut. Potensi desa harus dapat dimanfaatkan dengan baik agar memiliki daya Tarik, nilai jual yang nantinya mendukung terwujudnya desa wisata serta mampu membantu masarakat setempat dalam kesejahteraan ekonomi dan sosialnya. Kegiatan awal ini dilakukan untuk mengidentifikasi permasalahan dan kebutuhan kelompok PKK Desa Sumberagung. Hasil yang dicapai dari kegiatan Focus Group Discussion (FGD) tersebut, menjumpai bahwa masyarakat masih belum memanfaatkan potensi yang dimiliki secara optimal. Selama ini, masyarakat desa hanya menjual hasil susu sapi perah secara langsung pada KUD dengan harga murah tanpa adanya proses pengolahan terlebih dahulu. Selain itu, hasil susu perah juga hanya sebatas di salurkan kepada pabrik pengepul susu untuk dijadikan sebagai susu bubuk bermerk. Hal ini terjadi karena kurangnya pengetahuan masyarakat untuk pengembangan produk dan manajemen usahanya.
Berdasarkan hasil FGD yang telah dilakukan, perlu adanya Sosialisasi dan Pelatihan Penguatan Ekonomi Produktif Pengolahan Susu Sapi Murni Menjadi Produk Olahan yang Bervariasi dan Bernilai Jual Tinggi. Kegiatan ini sangat penting dilaskanakan untuk membantu desa alam menyiapakn kolaborasi desa sebagai desa wisata lingkar selorejo. Dengan memberikan sosialisasi dan pelatihan ini diharapkan masyarakat mampu mengelola potensi lokal yang ada menjadi lebih bernilai jual secara ekonomi sehingga mampu meningkatkan produktivitas dan daya saing desa yang pada akhirnya akan mampu meningkatkan kesejahteraan masyarakat secara keseluruhan. Produk Olahan susu yang dipilih dalam kegiatan pelatihan yang dibagi menjadi dua tahap yaitu pelatihan tahap pertama pembuatan stik susu dan kerupuk susu, kemudian pelatihan tahap dua praktek pembuatan keju dan sabun susu. Pemilihan keempat variasi produk olahan susu tersebut didasarkan pada proses pembuatannya yang cukup mudah, sifat produk yang awet, sangat diminati oleh konsumen dan memiliki perluasan bisnis yang luas.

Kegiatan sosialisasi dan pelatihan perlu terus dipantau melalui kegiatan pendampingan kepada kelompok PKK untuk mengukur tingkat keberhasilan dari pelatihan dan ketrampilan yang dimiliki masyarakat. Pendampingan dilakukan dari tahapan kelayakan produk, kualitas produk sampai dengan pemasaran produk. Contohnya seperti menggunakan kemasan plastik yang direkatkan dengan mesin Sealer, selain membuat tampilan kemasan lebih rapi, dengan pengemasan seperti itu produk akan jauh lebih awet. Tak lupa juga tim pengabdian 
menyarankan UKM Sumberagung untuk membuat design labelling, hal ini diperlukan agar masyarakat/ konsumen mampu mengenali produk susu UKM Sumberagung dengan mudah. Design labelling yang menarik juga dapat menjadi strategi ampuh dalam menjual produk agar lebih diminati oleh konsumen. Dalam hal pemasaran, agar produk lebih dikenal oleh masyarakat luas. Selain ini luaran dari kegiatan ini yang juga mendukung pemasaran produk UKM Sumberagung dengan memulai memanfaatkan sosial media yang ada seperti Facebook, Whatsapp, Instagram, dan sejenisnya dalam pemasaran produknya. Mitra harus mencoba untuk memasarkan produknya secara online, dikarenakan berdasarkan survei yang dilakukan oleh Asosiasi Penyelenggara Jaringan Internet Indonesia (APJII) sepanjang 2016 menemukan bahwa 132,7 juta orang Indonesia telah terhubung ke internet dengan total penduduk Indonesia sendiri sebanyak 256,2 juta orang (Kompas, 2016). Berarti 51,8\% orang Indonesia telah terhubung ke internet dan ini peluang besar untuk memasarkan yang tak ada sekat ruang dan waktu. Konsumen nantinya bisa saja tidak hanya dari dalam negeri namun juga bisa dari luar negeri.

Pengukuran hasil pencapaian kegiatan pengabdian kepada masyarakat dapat diamati dari ketercapaian tujuan dan target yang telah direncanakan. Pasca kegiatan pengabdian diaksanakan para peserta mengalami peningkatan informasi dan wawasan dalam pengembangan inovasi produk olahan susu serta manajemen wirausaha, dengan adanya wawasan inovasi produk, produktivitas dan daya saing UKM Desa Sumberagung semakin meningkat dan hal ini diharapkan mampu memperluas Multiplier effects yang positif bagi lingkungan sekitar. Dimana perkembangan usaha pengolahan produk olahan berbahan susu murni tersebut mampu menciptakan penyerapan tenaga kerja baru, baik secara langsung dalam hal produksi maupun secara tidak langsung seperti menjadi supplier produk. Hasil pelatihan dan pendampingan ini diharapkan mampu meningkatkan kesejahteraan masyarakat desa di bidang ekonomi dan sosial. 
Gambar 1 Skema Pendampingan UKM

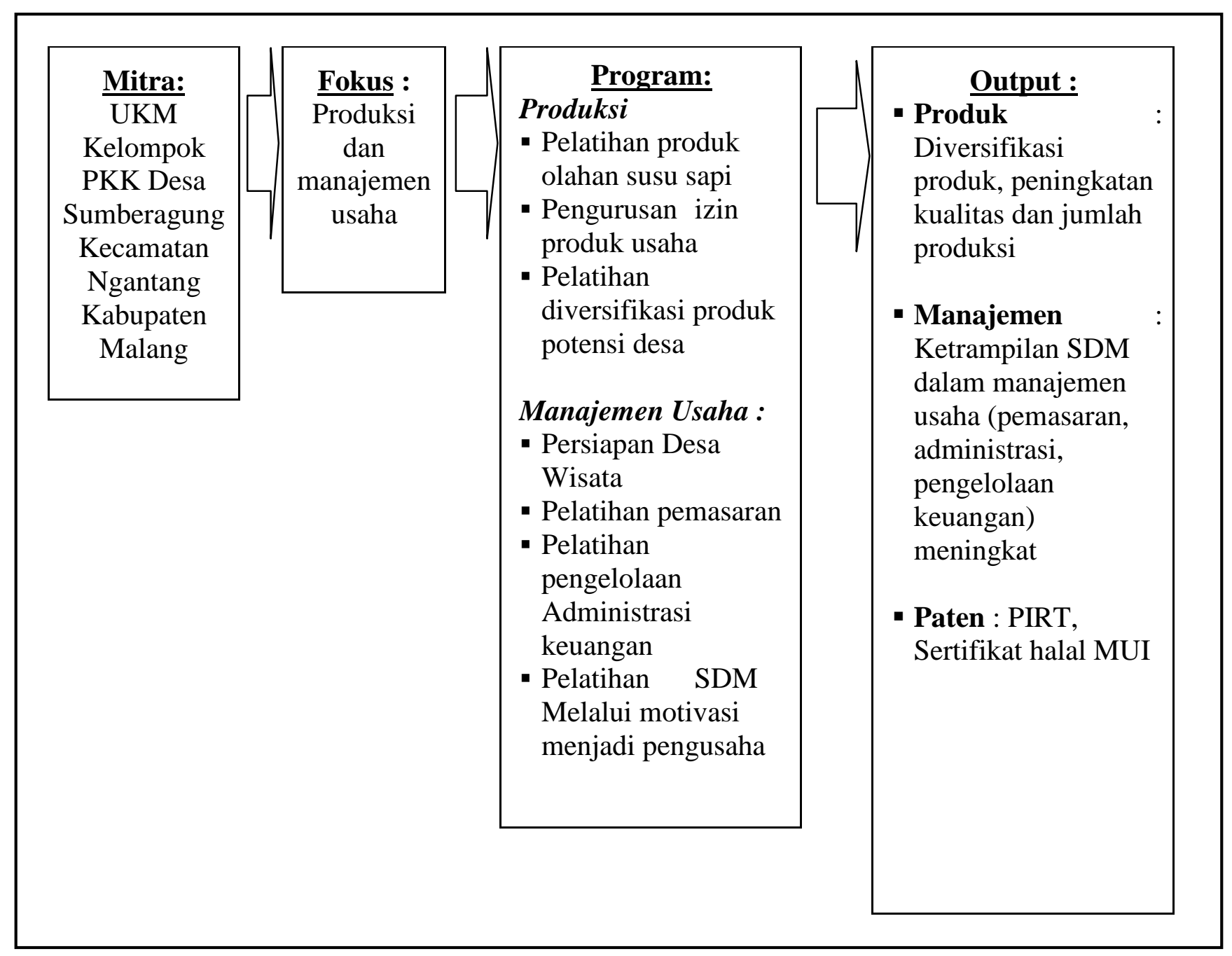


Sedangkan hasil yang dicapai dengan adanya kegiatan pendampingan UKM ini sebagai berikut:

Tabel 2. Hasil Yang Dicapai

\begin{tabular}{|c|c|c|}
\hline Aspek & Kegiatan yang dilakukan & Hasil \\
\hline Produksi & $\begin{array}{l}\text { Melaksanakan pelatihan diversifikasi produk } \\
\text { (keju, yogurt \&sabun susu) oleh tim pakar dari } \\
\text { Universitas Negeri Malang kerjasama dengan } \\
\text { dengan Mitra Usaha }\end{array}$ & $\begin{array}{l}\text { - Bertambahnya jumlah varian produk. } \\
\text { - Terdaftar di PIRT } \\
\text { - Memilliki sertifikat halal MUI } \\
\text { - }\end{array}$ \\
\hline \multirow[t]{3}{*}{ Manajemen } & 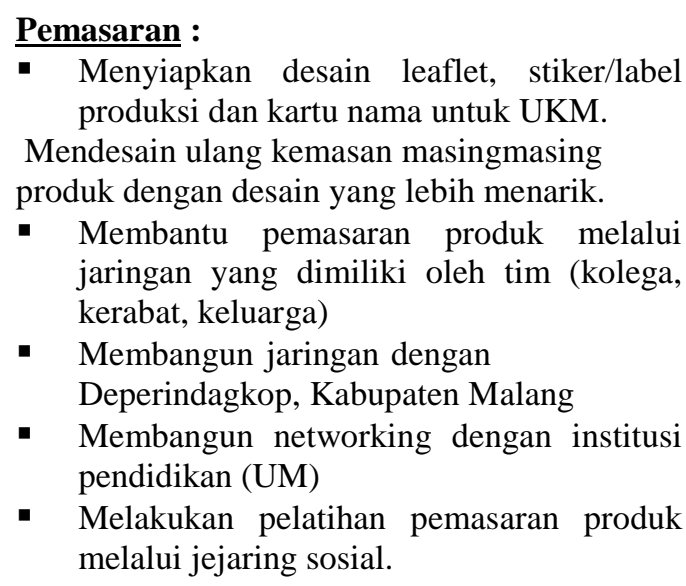 & 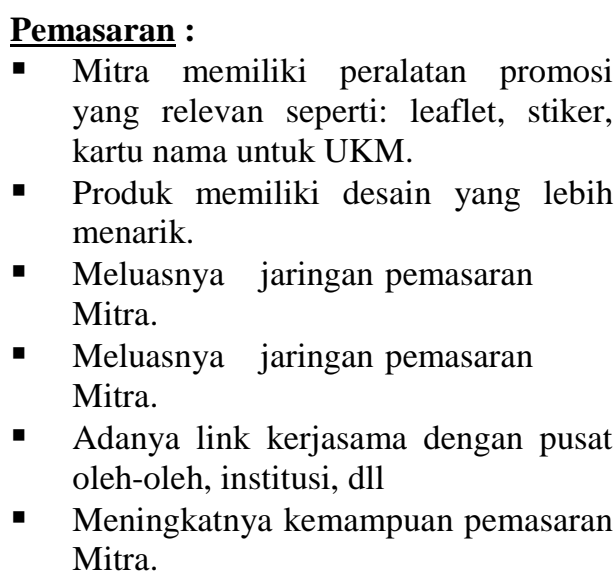 \\
\hline & $\begin{array}{l}\text { Administrasi Keuangan : } \\
\begin{array}{l}\text { Melakukan pelatihan manajemen keuangan } \\
\text { sederhana. }\end{array}\end{array}$ & $\begin{array}{l}\text { Administrasi Keuangan : } \\
\text { Mitra dapat membuat laporan } \\
\text { keuangan sederhana. } \\
\text { Mitra memiliki nota penjualan dengan } \\
\text { logo UKM nya. }\end{array}$ \\
\hline & 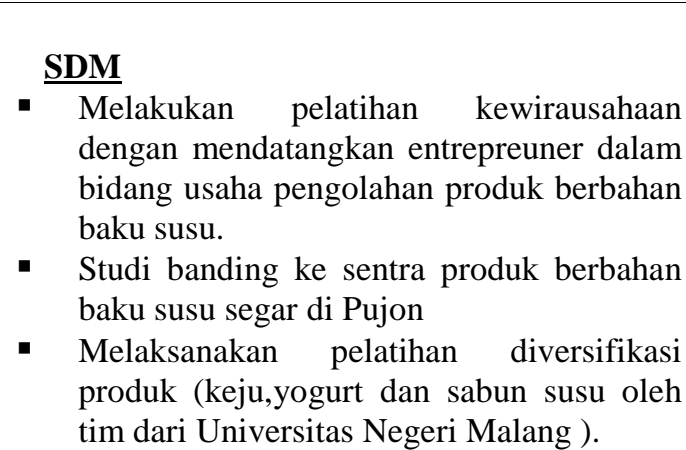 & $\begin{array}{l}\text { - } \frac{\text { SDM }}{\text { Meningkatmya mentalitas usaha bagi }} \\
\text { pelaku UKM. } \\
\text { - Meningkatnya wawasan UKM tentang } \\
\text { diversivikasi produk olahan susu dan } \\
\text { membuka link kerjasama dengan } \\
\text { pabrik cimory. } \\
\text { Meningkatnya kemampuan Mitra } \\
\text { dalam pengolahan susu menjadi } \\
\text { berbagai varian produk. }\end{array}$ \\
\hline
\end{tabular}

\section{KESIMPULAN}

Desa Sumberagung termasuk ke dalam wilayah kecamatan Ngantang Kabupaten Malang yang memiliki 6 dusun yang tersebar di wilayahnya yaitu dukuh Sumbermulyo, Dermosari, Sumbergadung, Rejosari,
Kebonsari, dan Bendorejo. Desa Sumberagung juga memiliki potensi peternakan sapi perah yang menjadi mata pencaharian $70 \%$ warganya. Tujuan kegiatan pendampingan UKM di Desa Sumberagung Kecamatan Ngantang Kabupaten 
Malang bekerjasama dengan mitra Kelompok PKK Desa Sumberagung adalah untuk meningkatkan pendapatan mitra dengan cara memproduksi dan memasarkan produk olahan susu sapi. Permasalahan yang dihadapi mitra adalah kurangnya pengetahuan dalam hal pengelolahan hasil susu sapi yang selama ini hanya sebatas disalurkan kepada KUD setempat dan Pabrik pengepul susu murni, tidak mengetahui cara pemasaran produk olahan susu sapi. Berangkat dari permasalahan tersebut, perlu diadakan pendampingan UKM kelompok PKK Desa Sumberagung melalui pelatihan pengolahan susu sapi menjadi produk unggulan desa dan dapat dijadikan sebagai produk khas Desa Sumberagung. Oleh karena itu, metode pelaksanaan yang dilakukan dalam kegiatan ini dengan memberikan informasi tentang gambaran variasi produk olahan susu sapi yang dapat membantu meningkatkan pendapatan kelompok PKK, pelatihan dan pendampingan pengelolahan susu sapi menjadi produk bernilai jual, pelatihan dan pendampingan softskill motivasi kerja dan creative thinking, serta pelatihan pendampingan pemasaran. Hasil dari kegiatan ini adalah meningkatnya pengetahuan dan ketrampilan mitra, terciptanya produk olahan susu sapi yang bernilai jual serta mampu mendukung program Desa Sumberagung sebagai desa wisata Lingkar Selorejo, publikasi pada media massa, serta adanya media sosial yang dapat mendukung dalam memasarkan potensi desa secara luas. Dengan semakin terbukanya pemikiran dan wawasan Para Pelaku UKM Sumberagung, maka sebaiknya kedepan dilakukan pendampingan secara berkelanjutan sehingga pengetahuan dan juga wawasan yang dimiliki oleh pelaku UKM Sumberagung semakin banyak dan utuh dengan begitu tujuan yang diinginkan dari seluruh aspek pendampingan dapat tercapai dengan optimal. Selain itu, para pelaku UKM Sumberagung juga masih memerlukan pendampingan legalitas terjaminnya produk yang dipasarkan mengingat inovasi produk yang dilakukan termasuk dalam produk makanan.

\section{REFERENSI}

Hendarmin, \& Kartika,M. (2016). Strategi Pengembangan Komoditas Unggulan Daerah. Prosiding SIGIM\#1, (halaman 161-168) UNU Kalbar

Kompas. (2016). 2016, Pengguna Internet di Indonesia Capai 132 Juta. diakses tanggal 18/8/2018 (http://tekno.kompas.com/read/2 016/10/24/15064727/2016.peng guna.internet.di.indonesia.capai. 132.juta)

Lembaga Penelitian Smeru, 2018. "Peta Upaya Penguatan Usaha Kecil/Mikro di Tingkat Pusat 2017/2018". Diakses 26 Juli 2018 dari www.smeru.or.id.

Rahayu, N S. (2009) "Profil Akses dan Kontrol Perempuan Pelaku Usaha Mikro Terhadap Sumber Daya Produktif di Kabupaten Bantul, Jurnal Utilitas,(ISSN 0854-7610, Vol XVI. No.2 Juli, 2008, FE UMY, Yogyakarta.

Sahban, H. 2015. Menebus Badai UMKM. CV Sah Media: Makassar.

Depkop. Diakses pada 20 Juli 2018, dari www.depkop.go.id 